\title{
The flux of radionuclides in flowback fluid from shale gas exploitation
}

\author{
S. Almond • S. A. Clancy • R. J. Davies • F. Worrall
}

Received: 21 January 2014 / Accepted: 28 May 2014 /Published online: 18 June 2014

(C) Springer-Verlag Berlin Heidelberg 2014

\begin{abstract}
This study considers the flux of radioactivity in flowback fluid from shale gas development in three areas: the Carboniferous, Bowland Shale, UK; the Silurian Shale, Poland; and the Carboniferous Barnett Shale, USA. The radioactive flux from these basins was estimated, given estimates of the number of wells developed or to be developed, the flowback volume per well and the concentration of $\mathrm{K}$ (potassium) and $\mathrm{Ra}$ (radium) in the flowback water. For comparative purposes, the range of concentration was itself considered within four scenarios for the concentration range of radioactive measured in each shale gas basin, the groundwater of the each shale gas basin, global groundwater and local surface water. The study found that (i) for the Barnett Shale and the Silurian Shale, Poland, the $1 \%$ exceedance flux in flowback water was between seven and eight times that would be expected from local groundwater. However, for the Bowland Shale, UK, the $1 \%$ exceedance flux (the flux that would only be expected to be exceeded $1 \%$ of the time, i.e. a reasonable worst case scenario) in flowback water was 500 times that expected from local groundwater. (ii) In no scenario was the $1 \%$ exceedance exposure greater than $1 \mathrm{mSv}$ - the allowable annual exposure allowed for in the UK. (iii) The radioactive flux of per energy produced was lower for shale gas than for conventional oil and gas production, nuclear power production and electricity generated through burning coal.
\end{abstract}

Responsible editor: Philippe Garrigues

Electronic supplementary material The online version of this article (doi:10.1007/s11356-014-3118-y) contains supplementary material, which is available to authorized users.

S. Almond $\cdot$ S. A. Clancy $\cdot$ R. J. Davies $\cdot$ F. Worrall $(\bowtie)$ Centre for Research into Earth Energy Systems (CeREES),

Department of Earth Sciences, Science Labs, Durham University, Durham DH1 3LE, UK

e-mail: Fred.Worrall@durham.ac.uk
Keywords Hydrofracking $\cdot$ NORM $\cdot$ Radium $\cdot$ Barium Potassium

\section{Introduction}

Shale is a common fine-grained, organic-rich, sedimentary rock and contains low concentrations of radionuclides which are adsorbed onto the organic material and clay minerals present (Smith 2011). During burial, kerogen within the shale converts to oil and gas (Pepper and Corvit 1995; Barker 1980), some of which is expelled, but a proportion remains in pore spaces (Cokar et al. 2010) or adsorbed onto the organic matter; some of this gas can subsequently be produced by hydraulic fracturing of the rock (Keshavarzi et al. 2012). The process of hydraulic fracturing requires the use of a fracturing fluid, which when pressurised generates fractures, invades the shale reservoir and then is returned to the surface through the wellbore after fracturing has been completed (Anderson et al. 2010; Gregory et al. 2011) - this is termed flowback fluid.

Flowback fluid is usually highly saline, contaminated with dissolved and suspended solids, heavy metals, fracking chemicals and naturally occurring radioactive material (NORM) of varying concentrations (Edmiston et al. 2011; Warner et al. 2013). Many sedimentary shale formations can contain high concentrations of NORM, such as radium, uranium and thorium (Walter et al. 2012). Uranium has been recorded in many shale formations at 0.01 to $0.02 \%$; the alum shale of Sweden contains as much as $0.5 \%$ (McKelvey and Nelson 2006). Radium-226 and radium228 are usually the most abundant radionuclides in flowback water and are the decay products of the uranium and thorium isotopes (Abdeen and Khalil 1995; Barbot et al. 2013). Radium is more soluble than the largely immobile uranium and thorium isotopes and therefore can become 
dissolved in pore water and hydraulic fracturing fluid (Smith 1992; Abdeen and Khalil 1995) and can then flow back to the surface after hydraulic fracturing (Edmiston et al. 2011). Equally, radon is the relatively short-lived daughter product of radium decay (half-life of $\mathrm{Rn}=222-3.8$ days, half-life of Ra-226=1,601 years), and so, although it is commonly found in groundwater (e.g. Mullinger et al. 2009), radon has not yet been featured in the analysis of flowback fluids. Radionuclides are a source of ionizing radiation, but ionizing radiation is common in our environment to be coming as it does from naturally occurring radon, food and water, medical exposure, cosmic rays and the Earth's gamma radiation (World Health Organisation 2012). For example in Cornwall, UK, natural radon exposure is particularly high due to the area being largely underlain by granitic rocks that are relatively rich in uranium and radium. For instance, the average radon level from 17,000 houses in the Carrick District of Cornwall was $145 \mathrm{~Bq} \mathrm{~m}^{-3}$ (becquerels per cubic metre) that is almost seven times greater than the English average of $21 \mathrm{~Bq} \mathrm{~m}^{-3}$ (UK Health Protection Agency 2012).

Typically for shale exploitation, a vertical well is deviated so that it can be drilled parallel to the shale reservoir (e.g. King 2010). The production casing is perforated, and hydraulic fractures are stimulated by injecting saline water with chemical additives (Kargbo et al. 2010; King 2010; Davies et al. 2012), and 'proppant' (e.g. sand) is used to keep the fractures open (King 2010; Bell and Brannon 2011; Frantz et al. 2005). Hydraulic fracture stimulation from a horizontal borehole is usually carried out in multiple stages (Frantz et al. 2005) with known volumes and compositions of fluid (Bell and Brannon 2011). A typical horizontal hydraulically fractured shale gas well will require between 7.6 and 19 million 1 of water, with this volume being dependent upon the length of the horizontal section of the well, depth and the number of fracturing stages (Rahm 2011). After hydraulic fracturing, the water is allowed to flow to the surface. As an example of the volumes of flowback water required by hydraulic fracturing, hydraulic fracturing in the $23,500-\mathrm{km}^{2}$ Haynesville Shale Basin in Northeast Texas and Northwest Louisiana began in 2007 (Fan et al. 2010). By the end of June 2010, there were thought to be 600 wells in the Haynesville Shale Basin, with 185 rigs in place (Fan et al. 2010). In the Haynesville Shale Basin, a well typically required $636-795 \mathrm{~m}^{3}$ of water for drilling, $15,899 \mathrm{~m}^{3}$ for hydraulic fracturing and $48-64 \mathrm{~m}^{3}$ for completion fluids (Pierce et al. 2010). However, shale basins differ in the volumes needed and horizontal wells in the Barnett Shale (Texas, USA) have been reported to use more than $13,638 \mathrm{~m}^{3}$ per treatment, and these thus produce huge amounts of flowback fluid (Harper 2008).

At the time of writing this paper, there are very few shale gas wells drilled in Europe. In the USA, it is a routine for flowback water to be disposed of by deep injection (Edmiston et al. 2011; Horner et al. 2011), but this is generally not permitted in Europe, leading to the question of how best to dispose of flowback fluid. Therefore, in this study published, sources of flowback fluid have been collected to produce the first assessment of the volumes of flowback fluid and the concentrations of radionuclides that could be expected if European countries went ahead with shale gas exploitation and put this in the context of other fluxes of radionuclides.

\section{Approach and methodology}

The data compiled for this study were all converted to common unit of $\mathrm{Bq}$ (SI unit of decays per second) as opposed to the often used unit of Curie $(\mathrm{Ci}=3.7 \times 1,010$ decays per $\mathrm{s})$, and it has been assumed, unless otherwise stated in the source, that the concentration data were for concentrations in the aqueous rather than the adsorbed phase.

To calculate the probability distribution of radionuclide flux from shale gas well development, the following were needed: the number of wells to be developed within a given basin, the volume of flowback fluid expected and the concentration of a particular radioactive element within the flowback fluid.

Estimates of the concentration of radioactive elements in flowback fluid were based upon the values reported in the literature for flowback fluid. A number of radionuclides could be expected to be present in flowback, but the dominant two are radium and potassium. Radium and potassium have welldefined isotopic abundances, and so, it is easy to convert concentration data into Bq.

For the number of wells and the volume of flowback fluid, three shales were considered.

\section{The Bowland Shale, UK}

The number of wells planned for the Bowland Basin cannot be officially clarified yet: It is estimated that between 1 and 10 wells were to be drilled in 2013. So far, one well has been drilled within the Bowland Shale, the Preese Hall well drilled and fractured in the Bowland Shale with the low-end estimate for flowback fluid volume for one well being 1,232 $\mathrm{m}^{3}$ with the high estimate being $6,627 \mathrm{~m}^{3}$ (Broderick et al. 2011). The Environment Agency's initial analysis of the flowback fluid from the Preese Hall well has recorded the presence of the radioactive material radium-226, and the highest concentration recorded was $90 \pm 12 \mathrm{~Bq} / \mathrm{kg}(102 \mathrm{~Bq} / \mathrm{kg}=3,027.027 \mathrm{pCi} / \mathrm{l})$ (Environment Agency 2011).

Silurian Shale, Poland

Since 2007, Poland has granted 111 shale gas exploration licences. By 2021, the licence holders should have developed 308 boreholes on 110 of these licences, including 122 
mandatory boreholes along with 186 optional ones. To date, 23 drillings have been made in Poland, with another 6 currently underway and another 41 new drilling projects due for development before the end of 2013. For this study, the minimum number of wells drilled and produced is 10 , with a maximum of 50. Lubien LE-2H well was drilled in Lubien near Pomerania Voivodeship, Poland. It has a depth of $4,075 \mathrm{~m}$, with a horizontal section of $1,000 \mathrm{~m}$ long with $17,322 \mathrm{~m}^{3}$ of water injected into the horizontal section of the well; this water was laden with 1,271 tonnes of quartz sand and $462 \mathrm{~m}^{3}$ of chemical additives (Panstwowy Instytut 2012). The operations produced $2,781 \mathrm{~m}^{3}$ of flowback fluid. Due to this fluid being in contact with strongly saline waters and the shale formation, it came back enriched with chlorides and barium salts (Panstwowy Instytut 2012).

\section{The Barnett Shale, USA}

The final scenario is for the Barnett Shale. The Barnett Shale is a shale gas province in North Central Texas (Willberg et al. 1998) with the unconventional gas reservoir extending for over $86,905 \mathrm{~km}^{2}$ (Ketter et al. 2006). The gas potential of the Barnett Shale was discovered in 1981, and in 2008, over 8,000 wells were being produced (Rickman et al. 2008; Kinley et al. 2008), and we can compare the K-40 from the Barnett Shale to those from Europe. If we assume that the Barnett Shale has roughly developed at a rate of $\sim 300$ wells per year over the last 27 years, in 2013, the number of wells will be approximately 8,300 wells. It is unlikely that in 2013, we would see a decrease in production; for this study, we therefore assume that the number of wells would stay the same; thus, the minimum number of wells would be 8,000 wells. The most common disposal method in the Barnett Shale is to truck it to distant wells and inject the flowback fluid back into the ground (Mcllvaine and James 2010).

\section{Comparative data}

To put the above estimates of radioactive flux from flowback fluid in shale basins into context, it is necessary to consider two situations: firstly, the release of radionuclides from other anthropogenic operations, and secondly, the level of radioactivity that might be expected from the natural background.

In this study, we propose that the most appropriate natural background with which to compare shale gas basins is the flux of radioactivity that would be expected from pumped groundwater. Two sets of groundwater were considered: firstly, background groundwater concentrations of radioactive elements within the shale gas basins themselves, and secondly, it was not always possible to obtain background concentrations for a particular basin and so groundwater concentrations from elsewhere in the world were used. It may be expected that data may be skewed towards higher values as radionuclide studies are likely to be carried out in regions where levels are known to be elevated or could be expected to be of concern. Not all reports of groundwater radioactivity were incorporated into the estimates. If the data source stated that the sampling location was close to, or could be influenced by, an external source of radionuclides, e.g. nuclear power stations, then the results were discarded. However, it cannot be guaranteed that no results are skewed by external radionuclide input as not all such sources would be noted in the literature.

Nuclear power discharge water will be contaminated with radionuclides. Above the activity of flowback fluid has been compared to the activity of naturally occurring groundwaters by predicting the total annual radiation output if natural waters were pumped in the same quantities as flowback fluid. Here, the same scenario was applied to radioactive produced waters from the nuclear power industry, i.e. if the same concentration as observed in nuclear power plant discharge water was pumped in the same volumes as flowback fluid, what would be the equivalent flux? This puts flowback fluid in context with other permissible radionuclide contaminations, and such an analysis was not possible for other sectors such as produced water from oil and gas installations because it was not possible to calculate the concentrations in the water involved. Alternatively, the distribution of produced water activity from nuclear power stations was calculated based on the total annual discharge $(\mathrm{Bq})$ from each UK station. This was used in conjunction with generic water usage values for nuclear power stations $(1 / \mathrm{MW} / \mathrm{h})$ and total UK energy output $(69 \mathrm{TW} / \mathrm{h})$ to estimate the activity of discharge from each power station in becquerels per litre.

The OSPAR Commission administers northwestern European countries' obligations to monitor the quality of discharges to the Atlantic under the Oslo and Paris Treaties. As part of their activities, the OSPAR Commission collects data on the discharge of radionuclides to the Atlantic from a number of countries and a number of sectors, and this includes the non-nuclear sector (OSPAR 2012a). Therefore, OSPAR Commission data are especially valuable as a comparator for a potential UK shale gas industry. Non-nuclear UK sector includes oil and gas extraction, titanium dioxide pigment operations, steel and rare earth production, medical industry, universities and research centres and the radiochemical production. All of these sectors have the potential to discharge radioactive substances into maritime areas. The medical sector comprises of hospitals, clinics and medically related laboratories and, in 2010, was only required to report the marine disposal of iodine-131 (OSPAR 2012a). Universities and research centres are interpreted by OSPAR to include all medical research, universities, educational establishments and research institutes (OSPAR 2012a). The universities and research centres also includes operators involved in pharmaceutical research and manufacturing as well as non-medical commercial laboratories. In 2010, there were three primary steel 
manufacturing plants in the UK. These plants operate by using a dry gas cleaning process, with any dust created removed from the stack and either recycled or sent to landfill- - this process does not discharge any liquid. Of particular importance is the discharge of produced waters from the oil and gas industry which is especially dominated by discharges from offshore installations in the North Sea.

\section{Stochastic assessment}

The concentration of the particular radionuclide, the flowback volume and the number of wells were defined across a range for each scenario. Ranges derived from the literature or company information were not considered to be the maximum and minimum values possible; rather, the range reported was taken as an estimate of 2 standard deviations of a normal distribution of that variable. Once the normal distribution was estimated for each of the concentration of the particular radionuclide, the flowback volume and the number of wells and then the flux of radionuclide were estimated by random sampling from each of these distributions, and this process was repeated 500 times in order to get 500 estimates of the flux of the radioactive element. Once the 500 estimates have been calculated, then it is possible to examine the distribution and cumulative distribution of the flux. From the cumulative frequency distribution, it was possible to assess the probability that the radionuclide flux will exceed a certain value, and as standard, this study considered the $1 \%$ exceedance flux, i.e. the flux that would have only a $1 \%$ chance of being exceeded, given the estimated ranges within that scenario.

\section{Human exposure}

In examining the absolute values of radioactive element flux from flowback fluid relative to other radioactive sources, we also considered these figures in the context of human health, as this is ultimately one of the concerns associated with hydraulic fracturing technology. For this calculation, it was assumed that the volume of water being used by a person on a daily basis was from flowback fluid, and then the radioactive flux to that person would be the case from each of the scenarios considered. From these flux scenarios for each basin, an annual dose was calculated and compared to the maximum annual safe dose as recommended by the UK Environment Agency (i.e. $1 \mathrm{mSv}$ ) (Environment Agency 2011)

Annual dose $=\frac{k A U}{N V}$

where $A$ is the total annual radioactive activity $(\mathrm{Bq}), V$ is the annual flowback volume used for each well ( $\mathrm{m}^{3} /$ year/well), $N$ is the number of wells in the shale gas basin, $U$ is the annual individual water usage per year in the UK ( $1 /$ year) as recorded by the UK Environment Agency (54,750 1/year), and $k$ is the conversion factor to convert to millisieverts. Values were taken from each scenario for each shale gas basin. Doses were calculated at the 50th and 99th percentiles of activity and flowback volume as calculated for each scenario. The activity value takes into account the sum of the activities of all measured radionuclides. However, radionuclides were only included if data were available for their activity in both flowback and groundwater, in order that a fair comparison could be made. For example, the exposure values for Poland do not include contribution from $\mathrm{K}-40$, as $\mathrm{K}-40$ data were only available for the flowback fluid.

\section{Results}

Radioactivity in groundwaters

The range of concentration of Ra-226, Ra-228 and K-40 found in each shale gas basin and in world groundwater is summarised in Table 1 with the full details in the Supplementary Material Table S1. Of particular note are the higher concentrations that occur naturally in the Poland Silurian and Barnett Shale Basins than the Bowland Shale Basin.

\section{Bowland Shale}

The highest and lowest radionuclide concentrations reported for the Preese Hall well were analysed in December 2010 (Environment Agency 2011). The thallium-208 and radium224 concentrations in the flowback fluid were constant in all the samples with radium-224 concentration consistently at $4 \mathrm{~Bq} / \mathrm{kg}$, and so for the minimum, we have used $3.9 \mathrm{~Bq} / \mathrm{kg}$ so the flux values can be calculated. The K-40 activity in the Bowland Shale flowback fluid was 112,958.74 Bq/year compared to an estimated $4,870 \mathrm{~Bq} /$ year if groundwater was pumped instead (Table 2, Fig. 1), showing that the flowback fluid contains more radioactive potassium than natural groundwater. The exposure estimates from K-40 activities of global groundwater were almost five times greater than those based on levels in UK groundwater.

The Ra-226 values for the Bowland Shale flowback fluid also exceed the natural groundwater values $(2,379,175 \mathrm{~Bq} /$ year compared to $1,460 \mathrm{~Bq} /$ year $)$. When calculated using the global distribution of groundwater Ra-226, however, the estimated activity of pumped water would be $1,650,000 \mathrm{~Bq} /$ year, a difference of 3 orders of magnitude from the local natural groundwater, similar to the measured exposure from flowback fluid. As with $\mathrm{K}-40$, seen in the global context, the increased activity 
Table 1 Summary of scenarios used for the analysis

\begin{tabular}{|c|c|c|c|c|c|c|c|c|c|}
\hline \multirow[t]{2}{*}{ Basin } & \multicolumn{3}{|c|}{ Radium-226 (Bq/l) } & \multicolumn{3}{|c|}{ Radium-228 (Bq/1) } & \multicolumn{3}{|c|}{ Potassium-40 (Bq/1) } \\
\hline & Upper & Lower & $n$ & Upper & Lower & $n$ & Upper & Lower & $n$ \\
\hline Poland & 85.0000 & 0.0040 & 129 & 2.1700 & 0.0040 & 129 & & & \\
\hline Barnett & 16.9000 & 0.0003 & 601 & 5.92 & 0.0000 & 593 & & & \\
\hline Bowland & 0.0500 & 0.0007 & 35 & & & 35 & 0.1900 & 0.0260 & 35 \\
\hline World & 85.0000 & 0.0003 & 1,239 & 5.92 & 0.0000 & 1,210 & 0.8900 & 0.0001 & 195 \\
\hline
\end{tabular}

from flowback fluid is much less significant when viewed relative to global values.

Surface waters should be considered as they are more directly linked to human exposure and environmental contamination. Surface water activity data were only available for the Bowland region and are based on national averages from reservoirs and rivers. Ra-226 data were not available for surface water measurements; however, we have considered Ra-226 activity to be analogous to total alpha activity, for which data were available. The total activity for Bowland flowback fluid is $\sim 2.5 \mathrm{MBq} /$ year, compared to $\sim 0.021 \mathrm{MBq} /$ year in surface waters, which has a difference of 2 orders of magnitude. This highlights a potentially large risk if surface waters were to become contaminated with flowback fluid. Radium and potassium are relatively soluble and therefore common in flowback fluid. They are not however the only naturally occurring sources of radiation in groundwater/ surface water. For the Bowland Shale, flowback fluid and groundwater have been compared to the total activity of an equivalent volume of UK surface water to assess the net impact that discharge of flowback fluid to waterbodies may have. These data show (Table 3) that water from local lakes, reservoirs and rivers has more than double the activity of groundwater (15,000 and 6,330 Bq/year, respectively). Total beta radiation activity for the volume pumped (analogous to $\mathrm{K}-40$, a beta emitter) is $11,600 \mathrm{~Bq} /$ year, and the total alpha activity (analogous to Ra-226) is 3,370 Bq/year.

\section{Polish Silurian Shale}

The Polish Geological Institute (2011) recorded one value for each of the elements in the flowback fluid from Poland, and therefore, it was difficult to give a concentration range for this shale gas basin. To create the cumulative distribution for $\mathrm{K}-40$, we have used the minimum and maximum values from the UK Environment Agency, 1 and $5.2 \mathrm{~Bq} / \mathrm{l}$, respectively (Environment Agency 2011), and the flowback fluid volume and the number of wells were as stated above. The 99th percentile values for K-40 flux are lower than those estimated for the Bowland Shale, but the flux for Ra-226 is estimated to be higher (Table 1). The higher Ra-226 flux in flowback fluid is reflected in a higher background groundwater flux of Ra226 based upon local information. It should be noted that the predicted $1 \%$ exceedance flux of K-40 is lower than the value predicted for global natural groundwater.

\section{Barnett Shale}

Rimassa et al. (2009) records the total dissolved solids in Northeast Texas at $147,000 \mathrm{mg} / \mathrm{l}$, and this is significantly more than that of Horner et al. (2011) who documents $39,570 \mathrm{mg} / \mathrm{l}$ (Table 3). The mean radium-226 value was $6.5 \mathrm{~Bq} / \mathrm{l}$, whilst the only radium-228 reading is $0.04 \mathrm{~Bq} / \mathrm{l}$. Potassium concentration in flowback fluid is recorded by Rimassa et al. (2009) as 1,580 mg/l. The predicted $1 \%$ exceedance fluxes from the Barnett Shale are higher than those predicted for either the Bowland Shale or the Silurian Basin at $2.5 \mathrm{GBq} / \mathrm{year}$, but rather like the situation for the Polish Silurian Basin, this flux is less than eight times what was expected from local, natural groundwater for the basin, i.e. the natural groundwater in the shale has higher levels of Ra-226. Indeed, the predicted $1 \%$ exceedance flux of Ra-228 is lower than that expected from natural groundwater, and when compared to global groundwater,

Table 2 Radioactive flux from each of the shale basins considered for four concentration scenarios

\begin{tabular}{|c|c|c|c|c|c|c|c|c|c|c|c|c|}
\hline \multirow[t]{2}{*}{ Scenario } & \multicolumn{3}{|c|}{ Flowback water flux } & \multicolumn{3}{|c|}{ Local natural groundwater } & \multicolumn{3}{|c|}{ Global natural groundwater } & \multicolumn{3}{|c|}{ Local natural surface water } \\
\hline & Ra-226 & Ra-228 & $\mathrm{K}-40$ & Ra-226 & $\mathrm{Ra}-228$ & $\mathrm{~K}-40$ & $\mathrm{Ra}-226$ & Ra-228 & $\mathrm{K}-40$ & Ra-226 & $\mathrm{Ra}-228$ & $\mathrm{~K}-40$ \\
\hline Barnett & $2,408,423$ & 5,544 & 1,615 & 347,241 & 88,152 & & $1,375,726$ & 87,728 & 12,922 & & & \\
\hline Bowland & 2,379 & & 113 & 1.5 & & 4.9 & 1,648 & & 22.8 & 3.4 & 11.6 & 6.8 \\
\hline Poland & 77,960 & & 4 & 10,777 & 290 & & 12,307 & 635 & 121 & & & \\
\hline
\end{tabular}

All values are the $1 \%$ exceedance values, and all are given in kilobecquerels per year 


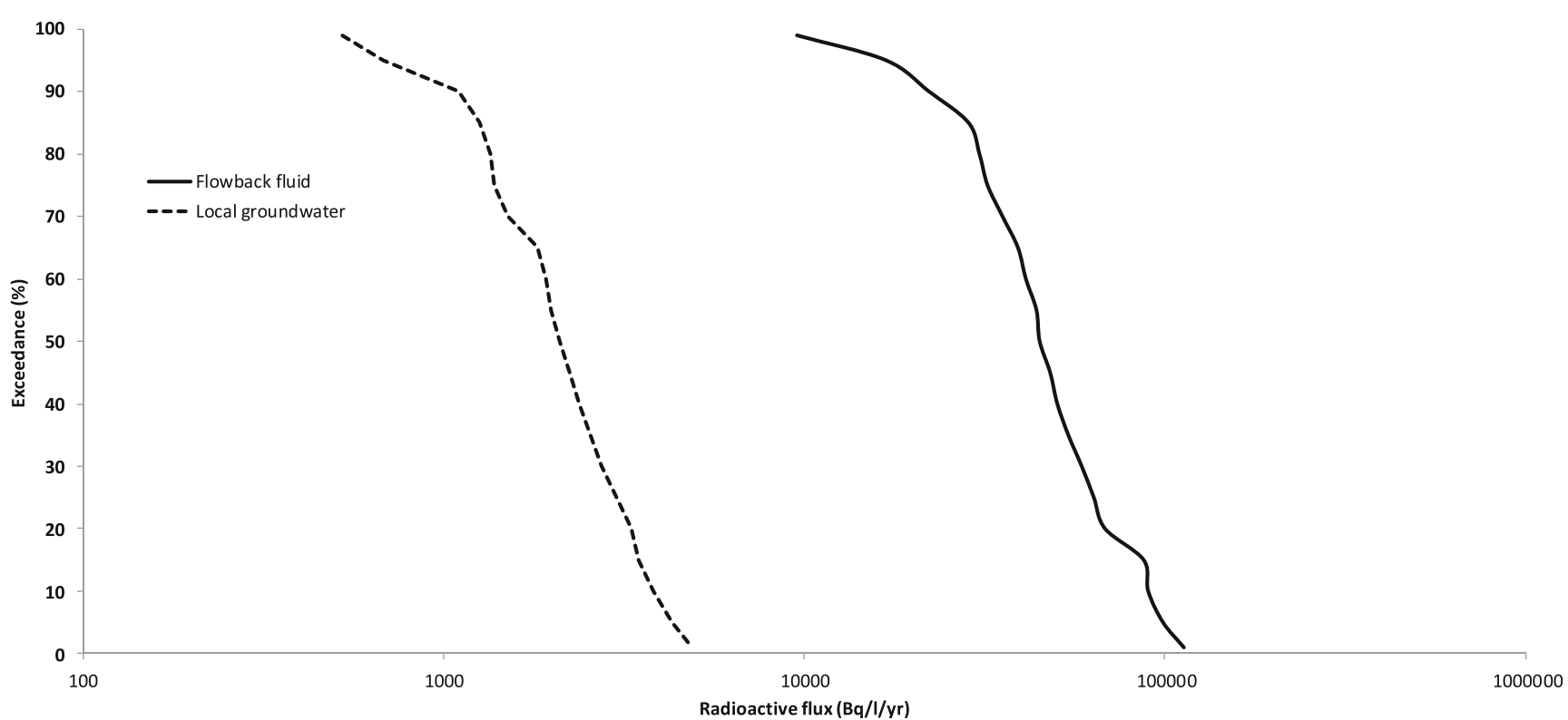

Fig. 1 Comparison of the exceedance curves for radioactive flux projected for the Bowland Shale based upon K-40 concentrations in local groundwater and for flowback fluids

even the estimated $1 \%$ exceedance flux of Ra-226 is less than twice that possible.

\section{Comparative emissions}

Produced water

In $2007, \sim 400$ million $\mathrm{m}^{3}$ of produced water from oil production was discharged into the North Sea, whilst only $\sim 85 \mathrm{~m}^{3}$ was injected into the subsurface. Treatment and overboard discharge has historically been the main option in the North Sea; however due to the economic benefits and environmental concerns, reinjection is becoming more popular (Paige and Murray 1994; Iversen et al. 2009). Reinjection of flowback fluid is very popular in US shale gas provinces (Edmiston et al. 2011).

The radionuclides discharged from the UK via produced water in 2010 from offshore oil and gas industries were as follows: Ra-226 (0.36 TBq), Ra-228 (0.13 TBq) and $\mathrm{Pb}-210$ (0.04 TBq) (OSPAR 2012b). There are 104 installations in the UK annually discharging a total of $196,333,229 \mathrm{~m}^{3}$ of water into the sea, excluding seawater

Table 3 Total activity for Bowland Shale waters

Activity (kBq/year) Flowback fluid Local groundwater Surface water

\begin{tabular}{llll}
\hline Alpha & 2,379 & 1.5 & 3.4 \\
Beta & 113 & 4.9 & 11.6 \\
Total & 2,492 & 6.3 & 15.0 \\
\hline
\end{tabular}

for pressure maintenance, of this $27,481,713 \mathrm{~m}^{3}$ is produced water (OSPAR 2012b). These volumes are considerably more than those potentially created by proposed UK shale gas activity. For example, the maximum recorded volume of flowback fluid from one well in Lancashire was $6,627 \mathrm{~m}^{3}$ (Regeneris Consulting 2011). If 25 wells (this is the very top estimate) were drilled in 2014, $165,675 \mathrm{~m}^{3}$ of flowback fluid would be returned to the surface. For comparative purposes, the discharges from the North Sea oil and gas installations were rescaled to the volumes expected for the Bowland Shale, and this would give fluxes of Ra-226 (2.2 GBq), Ra-228 (0.8 GBq) and $\mathrm{Pb}-210(0.2 \mathrm{GBq})$, i.e. 3 orders of magnitudes greater than those predicted from shale gas operations. Even if development continued at this extremely high level for 20 years, the maximum volume of flowback would be $3,313,500 \mathrm{~m}^{3}$, and so although this is an unrealistic scenario, it demonstrates that the UK not only currently manages much greater volumes of produced water for disposal than could be expected from the UK shale gas

Table 4 A comparison of expected $1 \%$ exceedance radioactive flux from flowback fluid for the shale gas basins with that which could be expected for water at the concentration of nuclear power discharge water

\begin{tabular}{lll}
\hline Scenario & Nuclear power discharge & Total flowback fluid activity \\
\hline Barnett & $435,658,912$ & $2,415,582$ \\
Bowland & 595,713 & 2,492 \\
Poland & $2,836,126$ & 77,964 \\
\hline
\end{tabular}

All values are in kilobecquerels per year 
Table 5 Annual exposure risks based on the hypothetical everyday use of flowback fluid and natural local groundwater for the three shale gas basins

\begin{tabular}{lll}
\hline Scenario & \multicolumn{2}{l}{ Exposure risk } \\
\cline { 2 - 3 } & 50 th & 99 th \\
\hline Barnett Shale & & \\
$\quad$ Flowback & 0.0605 & 0.0911 \\
$\quad$ Local groundwater & 0.0000 & 0.0000 \\
Bowland Shale & & \\
$\quad$ Flowback & 0.0413 & 0.0903 \\
$\quad$ Local groundwater & 0.0001 & 0.0002 \\
Silurian Shale, Poland & & \\
$\quad$ Flowback & N/A & 0.4291 \\
$\quad$ Local groundwater & 0.0291 & 0.0593 \\
UK conventional oil and gas & & N/A \\
$\quad$ Produced water & 13.7264915 & \\
\hline
\end{tabular}

All values are in millisieverts, and the recommended maximum annual dose is $1 \mathrm{mSv}$ (Environment Agency 2011)

industry but also even manages greater volumes of proportionately more radioactive water.

Other non-nuclear sectors

For the titanium dioxide industry, just one operator was reported to be discharging 8.02 and $4.92 \mathrm{GBq}$ of total alpha and beta/gamma (excluding tritium), respectively, from the UK (OSPAR 2012a).

The medical sector dominates the non-nuclear discharge from the UK. It is interpreted as being hospitals, clinics and medically related laboratories. The second largest contributor was radiochemical production, which in 2010 discharged 1.15 TBq of H-3 into the North Sea and Celtic Sea.

\section{Nuclear power discharge water}

The scenarios show that if an equivalent volume of nuclear power plant waste water was pumped, the contamination $(\mathrm{Bq})$ would be, in each case, 2 orders of magnitude larger than the measured values for pumped flowback fluid (Table 4). This highlights a comparatively small risk posed by contaminated flowback fluid, given the scale of nuclear power contamination. The total annual radiation flux to UK waters from nuclear power is $1.8 \times 10^{3} \mathrm{TBq}$ (calculated from Environment Agency 2011). In contrast, the maximum annual radiation flux due to flowback water at any of the sites studied was $90.2 \mathrm{MBq}$. This further highlights the minor contribution of fracking fluids to the overall UK radiation exposure.

\section{Human exposure}

Exposure from natural groundwater ranged up to $0.09 \mathrm{mSv}$ at the 99th percentile for the Barnett Shale but was as low as $0.0001 \mathrm{mSv}$ for the median exposure in the Bowland Shale (Table 5). The highest exposure predicted by this approach for the Bowland Shale with a calculated activity for flowback at the 99th percentile was $0.2 \mathrm{mSv}$; however, this is still only $20 \%$ of the maximum recommended annual exposure $(1 \mathrm{mSv}$, Environment Agency 2011). Furthermore, the 99th percentile exposure for the Bowland Shale is 65 times less than the exposure if the same analysis was repeated for UK produced water.

\section{Discussion}

One way of placing the radioactive flux from shale gas basins into context is to consider the flux of radioactivity per unit of energy produced - this could be considered the radioactive footprint of the energy source. This study has already considered the comparative flux from the nuclear energy and oil- and gas-produced waters, but the comparison could be made in terms of energy produced. If this analysis is performed for the UK, then the energy production from coal-fired power stations should also be considered. With respect to coal-fired power stations, the radioactive risk comes from burn products, especially ashes, rather than waste waters. A number of studies have detailed the enhanced radioactivity of the burn products from coal-fired power stations (Aytekin and Baldik 2012; Gur and Yaprak 2010; Papastefanou 2008; US Geological Survey 1999), and these studies were used to derive the likely radioactivity from UK coal-fired power stations. The mix of energy production in the UK is reported by Department of Energy and Climate Change (2012), and the likely energy production
Table 6 The radioactive footprint of UK energy production

\begin{tabular}{|c|c|c|c|c|c|c|}
\hline & \multirow[t]{2}{*}{ Coal } & \multirow[t]{2}{*}{ Nuclear } & \multicolumn{2}{|c|}{ Shale gas } & \multicolumn{2}{|l|}{ Oil and gas } \\
\hline & & & 50 th & 99th & $\mathrm{Ra}-226$ and $\mathrm{Ra}-228$ & Total \\
\hline Annual energy production $(\mathrm{TW} / \mathrm{h})$ & 19.7 & 62.7 & 0.36 & 0.36 & 1,370 & 1,370 \\
\hline $\begin{array}{l}\text { Radiation/unit energy production } \\
(\mathrm{Bq} / \mathrm{kW} / \mathrm{h})\end{array}$ & 374 & 28,740 & 3.2 & 7 & 0.39 & 9.2 \\
\hline
\end{tabular}


from the Bowland Shale basin is based on 10 gas-producing wells, given projections reported by Cuadrilla (2012). For the oil and gas industry, the total radioactive flux was considered alongside that of Ra-226 and Ra-228. This analysis shows that the highest radioactive footprint is for nuclear power production (Table 6) followed by coal power production and shale gas coming as the third. It should also be noted that contaminated groundwater coming to the surface at a point source could easily be remediated, and indeed, such systems have been proposed for shale gas exploitation (e.g. Nguyen et al. 2009) and radionuclide-specific technologies do exist for water treatment works (e.g. Gafvert et al. 2002). Where contamination has been discovered on the surface, it can be associated with older shale gas operations (Warner et al. 2013).

\section{Conclusions}

This study shows that shale gas exploitation will result in an increased flux of radioactive elements to controlled waters including to surface waterbodies. However, it is clear that fluxes are within a range of those that might be experienced elsewhere in the world from use of natural groundwaters, lower than the other discharges even from the non-nuclear sector and lower than those from other energy production including both conventional offshore oil and gas productions

\section{References}

Abdeen F, Khalil M (1995) Origin of NORM in Ras Budran Oil Field. Society of Petroleum Engineers, SPE, 029795

Anderson DM, Nobakht M, Moghadam S, Mattar L (2010) Analysis of production data from fractured shale gas wells. Society of Petroleum Engineers, SPE, 131787

Aytekin H, Baldik R (2012) Radioactivity of coals and ashes from Atalagzi coal-fired power plant in Turkey. Radiat Prot Dosim 149(2):211-215

Barbot E, Vidic NS, Kelvin B, Gregory S, Vidic RD (2013) Spatial and temporal correlation of water quality parameters of produced waters from Devonian-age shale following hydraulic fracturing. Environ Sci Technol 47:2562-2569

Barker C (1980) Primary migration: the importance of watermineral-organic matter interactions in the source rock. Probl Pet Migr 19-31

Bell CE, Brannon HD (2011) Redesigning fracturing fluids for improving reliability and well performance in horizontal tight gas shale applications. Society of Petroleum Engineers, SPE, 140107

Broderick J, Anderson K, Wood R, Gilbert P, Sharmina M, Footitt A, Glynn S, Nicholls F (2011) Shale gas: an updated assessment of environmental and climate change impacts. University of Manchester, A report commissioned by the co-operative and undertaken by researchers at the Tyndall Centre

Cokar, M., Kallos, M. S., Huang, H., Larter, S. R., Gates, I. D. (2010) Biogenic gas generation from shallow organic-matter-rich shales. Canadian Society for Unconventional Gas/Society of Petroleum Engineers. CSUG SPE 135323
Consulting R (2011) Economic impact of shale gas exploration and production in Lancashire and the UK: a report for Cuadrilla resources. Regerneris Consulting Limited, September, 2011

Cuadrilla Resources (2012) Water sourcing. Protecting the environment. http://www.cuadrillaresources.com/protecting-our-environment/ water/water-sourcing/. Accessed 24 Oct 2012

Davies RJ, Mathias S, Moss J, Hustoft S, Newport L (2012) Hydraulic fractures: how far can they go? Mar Pet Geol 37(1):1-6

Department of Energy and Climate Change (2012). Oil discharge with produced water. http://og.decc.gov.uk/en/olgs/cms/data_maps/field_ data/oil_discharged/oil_discharged.aspx. Accessed 19 Oct 2012

Edmiston PL, Keener J, Buckwald S, Sloan B, Terneus J (2011) Flow back water treatment using swellable organosilica media. Society of Petroleum Engineers, SPE, 148973

Environment Agency (2011) Shale gas north west - monitoring of flow back water

Fan, L., Thompson, J. W., Robinson, J. R. (2010) Understanding gas production mechanism and effectiveness of well stimulation in the Haynesville Shale through reservoir simulation. Society of Petroleum Engineers and Canadian Society for Unconventional Gas. CSUG/SPE 136696

Frantz JH, Williamson JR, Sawyer WK, Johnston D, Waters G, Moore LP, MacDonald RJ, Pearcy M, Ganpule SV, March KS (2005) Evaluating Barnett Shale production performance using an integrated approach. Society of Petroleum Engineers, SPE, 96917

Gafvert T, Ellmark C, Holm E (2002) Removal of radionuclides at a waterworks. J Environ Radioact 63(2):105-115

Gregory KB, Vidic RD, Dzombak DA (2011) Water management challenges associated with the production of shale gas by hydraulic fracturing. Mineral Soc Am 7(3):181-186

Gur F, Yaprak G (2010) Natural radionuclide emission from coal-fired power plants in the southwestern of Turkey and the population exposure to external radiation in their vicinity. J Environ Sci Health, Part A: Tox Hazard Subst Environ Eng 45(14):1900-1908

Harper JA (2008) The Marcellus Shale - an old "new" gas reservoir, in Pennsylvania geology. Pennsylvania Dept Conserv Natl Resour 38(1):1-22

Horner P, Halldorson B, Slutz J (2011) Shale gas water treatment value chain - a review of technologies including case studies. Society of Petroleum Engineers, SPE, 147264

Iversen PE, Stokke R, Bloor P, Unger S, Nilsen H-G, Jarrah J (2009) Assessment of impacts of offshore oil and gas activities in the NorthEast Atlantic. OSPAR Commission, Offshore Industry Service

Kargbo DM, Wilhelm RG, Campbell DJ (2010) Natural gas plays in the Marcellus Shale: challenges and potential opportunities. Environ Sci Technol 44(15):5679-5684

Keshavarzi R, Mohammadi S, Bayesteh H (2012) Hydraulic fracture propagation in unconventional reservoirs: the role of natural fractures. Am Rock Mech Assoc ARMA 12-129

Ketter A, Daniels JL, Heinze JR, Waters G (2006) A field study in optimizing completion strategies for fracture iniitation in Barnett shale horizontal wells. Society of Petroleum Engineers - Production \& Operations, 23(3):373-378

King GE (2010) Thirty years of gas shale fracturing: what have we learned? Society of Petroleum Engineers, SPE, 133456

Kinley TJ, Cook LW, Breyer JA, Jarvie DM, Busbey AB (2008) Hydrocarbon potential of the Barnett Shale (Mississippian), Delaware Basin, west Texas and southern New Mexico. AAPG Bull 92(8):967-991

McKelvey VE, Nelson JM (2006) Characteristics of marine uraniumbearing sedimentary rocks. Econ Geol 45:35-53

Mcllvaine R, James A (2010) The potential of gas shale. World Pumps 7: $16-18$

Mullinger NJ, Binley AM, Pates JM, Crook NP (2009) Radon in chalk streams: spatial and temporal variation of groundwater sources in the Pang and Lambourn catchments, UK. J Hydrol 339(3-4):172-182 
Nguyen PD, Weaver JD, Rickman RD, Sanders MW (2009) Application of diluted consolidation systems to improve effectiveness of proppant flowback remediation-laboratory and field results. Soc Pet Eng Prod Oper 24(1):50-59

OSPAR Commission (2012a) Discharges of radionuclides from the nonnuclear sectors in 2010. Radioactive Substances Series, OSPAR Commission, Paris

OSPAR Commission (2012b) Discharges, spills and emissions from offshore oil and gas installations in 2010. OSPAR Commission, Paris

Paige RW, Murray LR (1994) Re-injection of produced water-field experience and current understanding. Society of Petroleum Engineers, SPE, 28121

Panstwowy Instytut Geologiczny (2012) The Lebien report. Press release: environmental impact of hydraulic fracturing treatment performed on the Lebien LE-2H Well. Panstwowy Instytut Geologiczny. Panstwowy Instytut Badawczy

Papastefanou C (2008) Radioactivity of coals and fly ashes. J Radioanal Nucl Chem 275(1):29-35

Pepper AS, Corvit PJ (1995) Simple kinetic models of petroleum formation. Part 1: oil and gas generation from kerogen. Mar Pet Geol 12(3):291-319

Pierce DA, Bertrand K, Vasiliu CC (2010) Water recycling helps with sustainability. Society of Petroleum Engineers, SPE, 134137

Polish Geological Institute - National Research Institute, Koniecznska M, Woznicka M, Antolak O, Janica R, Lichtarski G, Nidental M, Otwinowski J, Starzycka A, Stec B, Wrobel G (2011) Environmental aspects of hydraulic fracturing treatment performed on the Lebien LE2H well. Final Report. Polish Geological Survey, Warsaw

Rahm D (2011) Regulating hydraulic fracturing in shale gas plays: the case of Texas. Energy Policy 39:2974-2981
Rickman R, Mullen M, Petre E, Grieser B, Kundert D (2008) A practical use of shale petrophysics for stimulation design optimization: all shale plays are not clones of the Barnett Shale. Society of Petroleum Engineers, SPE, 115258

Rimassa SM, Howard PR, Blow KA (2009) Optimizing fracturing fluids from flowback water. Abstract SPE Tight Gas Completions Conference, San Antonio

Smith KP (1992) An overview of naturally occurring radioactive materials (NORM) in the petroleum industry. Environmental Assessment and Information Sciences. Division, Argonne National Laboratory

Smith AL (2011) First correlation of NORM with a specific geological hypothesis. Society of Petroleum Engineers, SPE, 138136

United Kingdom Health Protection Agency (2012) Thousands of households in a part of Cornwall with historic radon problems are being offered a free test for levels of the radioactive gas radon. Press release 10th January 2012

United States Geological Survey Fact Sheet FS-142-99 (1999) Naturally occurring radioactive materials (NORM) in produced water and oilfield equipment - an issue for the energy industry

Walter GR (2012) Effect of biogas generation on radon emissions from landfills receiving radium-bearing waste from shale gas development. J Air Waste Manag Assoc 62(9):1040-1049

Warner NR, Christie CA, Jackson RB, Vengosh A (2013) Impacts of shale gas wastewater disposal on water quality in Western Pennsylvania. Environ Sci Technol 47:11849-11857

Willberg DM, Steinsberger DN, Hoover R, Card RJ, Queen J (1998) Optimization of fracture cleanup using flowback analysis. Society of Petroleum Engineers, SPE, 39920

World Health Organisation (2012) Ionizing radiation in our environment.

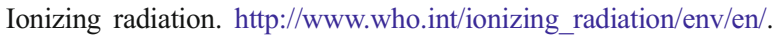
Accessed 19 Nov 2012 